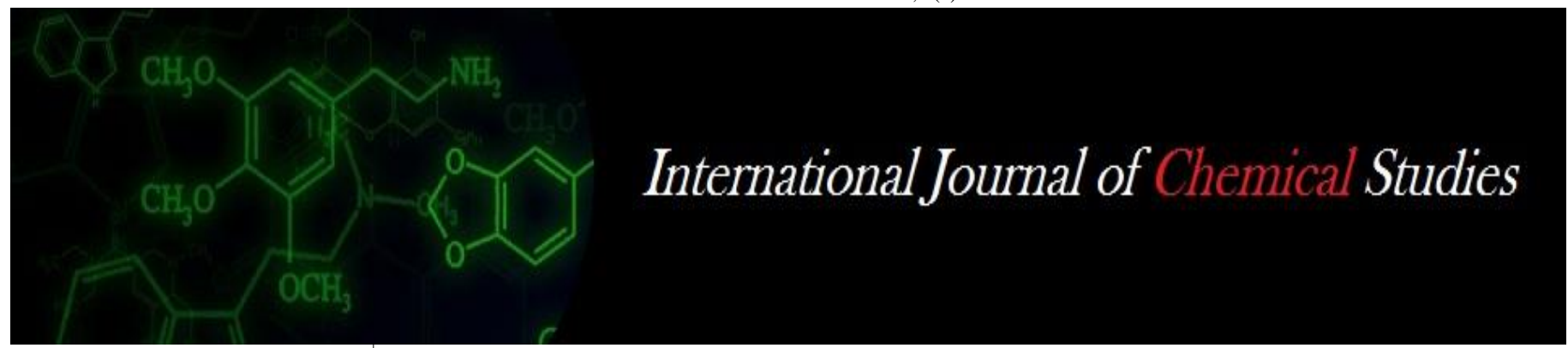

P-ISSN: 2349-8528

E-ISSN: 2321-4902

www.chemijournal.com

IJCS 2020; 8(1): 2612-2616

(C) 2020 IJCS

Received: 09-11-2019

Accepted: 13-12-2019

Vignesh M

Dept. Entomology, Sethu

Bhaskara Agricultural College

and Research Foundation,

Karaikudi, Tamil Nadu, India

Patil RK

Department of Agricultural

Entomology, University of

Agricultural, Sciences,

Dharward, Karnataka, India

Corresponding Author: Vignesh M

Dept. Entomology, Sethu Bhaskara Agricultural College and Research Foundation, Karaikudi, Tamil Nadu, India

\section{In vitro evaluation of biorationals and their mixed compounds against the melon aphid Aphis gossypii Glover}

\section{Vignesh $M$ and Patil RK}

DOI: https://doi.org/10.22271/chemi.2020.v8.i1an.8666

\begin{abstract}
In recent days sucking pests are getting more attention due to their efficiency to withstand the chemical pesticides by various mechanisms like resistance and resurgence. Usage of chemical pesticides can be reduced by using the biorational pesticides. Biorationals are any type of insecticides active against pest populations, but relatively innocuous to non target organisms and therefore, helpful in biological control. Here some of the biorationals and their mixers are tested against aphids (Aphis gossypii Glover) under laboratory condition in order to find the best biorational pesticide and their combination which leads maximum mortality of aphids and could serve as a better alternative for the chemical pesticides. Four botanicals \{Neem seed kernel extract (NSKE), Pongamia seed extract (PSE), Custard apple seed extract (CASE) and Asafoetida\}, two entomopathogenic fungi (Beauvaria bassiana and Lecaenicillium lecanii), one organic oil product \{Agricultural spray oil (ASO) @ 2ml/1 $\}$ and five combinations of them has been tried. Among the combinations tested, Agricultural spray oil + Custard apple seed extract + Pongamia seed extract + Neem seed kernel extract (2:1:2:2)@5\% has given higher cumulative mortality (100\%) after $72 \mathrm{hrs}$ of treatment. And the most efficient entomopathonenic fungus against A. gossypii was Lecaenicillium lecanii IOF 1 strain which gave the mortality percent of 83.40. The steps, results and the future aspects of the study are discussed briefly in this paper.
\end{abstract}

Keywords: Botanicals, Entomopathogenic fungi, Aphis gossypii, Mortality percentage

\section{Introduction}

Sucking pests are creating alarming level of loss in the crop production both in the open field and greenhouse condition. Among the various sucking pests, heavy infestation by melon aphids or cotton aphids, Aphis gossypii Glover is reported to be common due to their higher reproducing capacity and their efficiency to get resistance against most of the chemical pesticides currently in use (Sedlacek and Townsend, 1990; Shipp et al., 1991; Bennison, 1992; Hassan et al., 2008) ${ }^{[32,33,4]}$. With the increase in the levels of aphids, it is reported that the fruit parameters of the vegetables were decreased causing enough damage to the economic yield (Yasarakinci and Hincal, 1997; Tehri et al., 2014) ${ }^{[41,36]}$. Biorationals are any type of insecticides active against pest populations, but relatively innocuous to non target organisms and therefore, non-disruptive to biological control i.e. plant extracts, insect pathogens, etc (Crump et al., 1999, Eilenberg et al., 2001, Ware and Whitacre 2004) ${ }^{[7,9,40]}$. Under both lab and field conditions the neem products were reported to be most effective against sucking pests especially against aphids (Ascher et al., 1984; Lowery et al., 1993; Kulat et al., 1997; Biswas, 2013; Chaudhary et al., 2017) ${ }^{[2,23,18,5,6]}$. Several workers reported pongamia seed extract as an effective pesticide against large number of insect pests (Stein and Klingauf 1990; Katole et al., 1993; Hiremath et al., 1997, Kumar and Singh, 2002, Elena et al., 2014) [34, 16, 15, $19,10]$. Oil extracts from the seeds of sugar apple (Cashew) tested in both laboratory and field trials have shown the immense potential of cashew seed extracts to control the major sucking pests of greenhouse such as silver whiteflies, aphids and mites due to the active principle Neoannonin present in it (Kawazu et al., 1989; Rupprecht et al., 1990; Lin et al., 2009) [17, 29, ${ }^{21]}$. There are also studies stating that combination of botanicals causing major breakthrough in the pest management like pongamia and neem seed extracts mixed together have also shown synergetic effect against two spotted spider mites and aphids in both laboratory and field 
condition studies (Rao et al., 2002; Venkatesan et al., 2007) [28, 38]. Vignesh et al., 2019 also found promising results when they combined Pongamia, Neem, cashew seed extracts and the organic oil against two spotted spider mites. The mixed extracts of Pongamia +aloe + NSKE recorded higher mortality $(77.6 \%)$ followed by agave + chilli $(71.13 \%)$ and NSKE (65.44\%) which was more than any of the botanicals used alone under the laboratory condition (Barapatre, 2001; Loganathan et al., 2006) [3, 22]. Beauveria bassiana and Lecanicillium lecanii are the two most important entomopathogenic fungi tested against most of the sucking pests and proved to be effective in causing the mortality (Ugine et al., 2005; Mhazo et al. 2011; Erler et al., 2013;

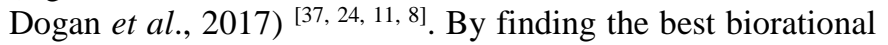
combinations it will not only form the alternate tool for chemical pesticides but also be useful in the formation of integrated pest management strategies for the eco-friendly pest management.

\section{Material and Methods}

In vitro evaluation of different biorationals against aphids was done in the laboratory condition of Department of Entomology, UAS, Dharwad during the two seasons of 2017 \& 2018.

\subsubsection{Experimental layout}

Location: Laboratory, Department of entomology, UAS, Dharwad.

Treatments: 13

Replications: 3

Experimental design: CRD

Table: Treatment details

\begin{tabular}{|c|c|c|c|c|}
\hline \multicolumn{2}{|c|}{ Treatment Details } & Trade name & Dosage & Source \\
\hline T1 & Beauvaria bassiana & & $108 \mathrm{CFU} / \mathrm{ml}$ & IOF, UAS,DWD \\
\hline T2 & Lecaenicillium lecanii & & $108 \mathrm{CFU} / \mathrm{ml}$ & IOF, UAS,DWD \\
\hline T3 & Hing (Asafoetida) & - & $0.125 \%$ & Prepared \\
\hline T4 & Neem seed kernel extract (NSKE) & - & $5 \%$ & prepared \\
\hline T5 & Pongamia seed extract (PSE) & - & $5 \%$ & prepared \\
\hline T6 & PSPE+NSKE (1:1) & - & $5 \%$ & prepared \\
\hline T7 & Custard apple seed extract (CASE) & - & $5 \%$ & prepared \\
\hline T8 & CASE+NSKE (1:1) & - & $5 \%$ & prepared \\
\hline T9 & CASE+PSE (1:1) & - & $5 \%$ & prepared \\
\hline $\mathrm{T}_{10}$ & CASE+PSE+NSKE (1:2:2) & - & $5 \%$ & prepared \\
\hline $\mathrm{T}_{11}$ & Agro spray oil (ASO) & SPELL & $2 \mathrm{ml} / 1$ & Vinayak oil industries, Mumbai \\
\hline $\mathrm{T}_{12}$ & ASO+ CASE+PSP+NSKE (2:1:2:2) & - & $5 \%$ & Dow Agro Sciences \\
\hline $\mathrm{T}_{13}$ & Standard check Spinosad 45 SC & Tracer & $0.5 \mathrm{ml} / 1$ & \\
\hline $\mathrm{T}_{14}$ & Untreated control & & & \\
\hline
\end{tabular}

\section{Essential biopesticides}

For the preparation of various botanicals and their combination the standard procedure followed by Vignesh et al., $2019^{[39]}$ is used.

\section{Source of inoculums}

Aphid population was maintained in the parthenocarpic cucumber plants grown under greenhouse without spraying any chemical in Hi-Tech horticulture farm, UAS, DWD.

\section{Treating aphids with biorationals}

Parthenocarpic cucumber leaves were used for the treatment. First the leaves collected from the pesticide free field were washed and cutted into the circular shape with the size of petriplates to fit inside them. Then those leaves were dipped inside the prepared chemicals and followed by which they were kept above the mesh cloth for a while to remove the excess water on the leaves surface. Then the treated leaves were shifted to the petriplates. Three replications of twenty five aphids and mites adults were taken separately and were provided with the leaves treated within the petriplates. The per cent mortality of aphids was calculated starting from one day after the treatment (DAT). Aphids which weren't shown any movement while touched using the camel brush is taken as dead or mortal.

\section{Observations}

1. Observations were made at one DAT at an interval of 24 hr till 72 hrs.

2. Per cent mortality of aphids and mites were calculated and corrected using the Schneider-Orelli's correction factor formula.

Mortality percentage $=\left\{\frac{\text { Total number of aphids- Dead aphids }}{\text { Total number of aphids }}\right\} \times 100$

Corrected morality percentage $=\frac{\text { Mortality } \% \text { in treated }- \text { Mortality } \% \text { in control }}{100-\text { Mortality } \% \text { in control }} \times 100$

\section{Statistical analysis}

The data on mean population of insects were subjected to arc sin transformation and analyzed statistically. The treatment mean values were compared by LSD at 5 per cent probability to access the effective treatment (Gomez and Gomez, 1984).

\section{Results}

Results of laboratory studies on the efficiency of various biorationals tested on aphids (A. gossypii) during 2017 and 2018 is presented on the Table 1. 
Table 1: In vitro evaluation of biopesticides and botanicals bio efficacy on A. gossypii (2017) \& (2018)

\begin{tabular}{|c|c|c|c|c|c|c|c|c|c|}
\hline \multirow{3}{*}{ Treatment } & \multicolumn{9}{|c|}{ Corrected mortality (\%) } \\
\hline & \multicolumn{3}{|c|}{2017} & \multicolumn{3}{|c|}{2018} & \multicolumn{3}{|c|}{ Pooled } \\
\hline & $24 \mathrm{hrs}$ & 48hrs & $72 \mathrm{hrs}$ & $24 \mathrm{hrs}$ & 48hrs & 72hrs & $24 \mathrm{hrs}$ & $48 \mathrm{hrs}$ & $72 \mathrm{hrs}$ \\
\hline $\mathrm{T}_{1}$ : Beauveria bassiana @ 108 $\mathrm{CFU} / \mathrm{g}$ & $\begin{array}{c}22.54 \\
(28.33)^{\mathrm{e}}\end{array}$ & $\begin{array}{c}39.52 \\
(38.93)^{\mathrm{e}}\end{array}$ & $\begin{array}{c}64.86 \\
(53.62)^{\mathrm{e}}\end{array}$ & $\begin{array}{c}23.20 \\
(28.79)^{\mathrm{d}}\end{array}$ & $\begin{array}{c}40.62 \\
(39.58)^{\mathrm{f}}\end{array}$ & $\begin{array}{c}65.76 \\
(54.17)^{\mathrm{e}}\end{array}$ & $\begin{array}{c}22.87 \\
(28.56)^{\mathrm{d}}\end{array}$ & $\begin{array}{c}40.07 \\
(39.26)^{\mathrm{f}}\end{array}$ & $\begin{array}{c}65.31 \\
(53.89)^{\mathrm{f}}\end{array}$ \\
\hline $\mathrm{T}_{2}:$ Lecanicillium lecanii @ $10^{8} \mathrm{CFU} / \mathrm{g}$ & $\begin{array}{c}33.97 \\
(35.63)^{\mathrm{c}}\end{array}$ & $\begin{array}{c}60.43 \\
(50.99)^{\mathrm{d}}\end{array}$ & $\begin{array}{c}82.90 \\
(65.55)^{\mathrm{c}}\end{array}$ & $\begin{array}{c}36.78 \\
(37.32)^{b}\end{array}$ & $\begin{array}{c}61.09 \\
(51.39)^{\mathrm{e}}\end{array}$ & $\begin{array}{c}83.90 \\
(66.321)^{\mathrm{c}}\end{array}$ & $\begin{array}{c}35.37 \\
(36.48)^{\mathrm{c}}\end{array}$ & $\begin{array}{c}60.76 \\
(51.19)^{\mathrm{e}}\end{array}$ & $\begin{array}{c}83.40 \\
(65.93)^{\mathrm{c}}\end{array}$ \\
\hline T3: Hing (Asafoetida) @ $0.125 \%$ & $\begin{array}{c}27.14 \\
(31.38)^{\mathrm{d}}\end{array}$ & $\begin{array}{c}35.02 \\
(36.26)^{\mathrm{e}}\end{array}$ & $\begin{array}{c}41.90 \\
(40.32)^{\mathrm{e}}\end{array}$ & $\begin{array}{c}29.33 \\
(32.78)^{\mathrm{c}}\end{array}$ & $\begin{array}{c}33.68 \\
(35.46)^{\mathrm{h}}\end{array}$ & $\begin{array}{c}40.95 \\
(39.78)^{\mathrm{f}}\end{array}$ & $\begin{array}{c}28.24 \\
(32.09)^{\mathrm{d}}\end{array}$ & $\begin{array}{c}34.35 \\
(35.86)^{\mathrm{g}} \\
\end{array}$ & $\begin{array}{c}41.43 \\
(40.05)^{\mathrm{g}}\end{array}$ \\
\hline $\begin{array}{r}\mathrm{T}_{4} \text { : Neem seed kernel ex } \\
\text { @ } 5 \%\end{array}$ & $\begin{array}{c}40.39 \\
(39.44)^{b}\end{array}$ & $\begin{array}{c}63.90 \\
(53.05)^{\mathrm{d}}\end{array}$ & $\begin{array}{c}76.27 \\
(60.82)^{\mathrm{d}}\end{array}$ & $\begin{array}{c}45.51 \\
(42.41)^{\mathrm{a}}\end{array}$ & $\begin{array}{c}64.57 \\
(53.45)^{d}\end{array}$ & $\begin{array}{c}75.60 \\
(60.37)^{\mathrm{d}}\end{array}$ & $\begin{array}{c}42.95 \\
(47.05)^{\mathrm{b}}\end{array}$ & $\begin{array}{c}64.24 \\
(53.25)^{\mathrm{d}}\end{array}$ & $\begin{array}{c}75.93 \\
(60.60)^{\mathrm{d}}\end{array}$ \\
\hline $\mathrm{T}_{5}$ : Ponga & $\begin{array}{c}36.19 \\
(36.97)^{\mathrm{c}} \\
\end{array}$ & $\begin{array}{c}58.43 \\
(49.83)^{\mathrm{d}} \\
\end{array}$ & $\begin{array}{c}64.19 \\
(53.22)^{\mathrm{e}} \\
\end{array}$ & $\begin{array}{c}38.52 \\
(38.35)^{\mathrm{b}}\end{array}$ & $\begin{array}{c}56.33 \\
(48.62)^{\mathrm{e}}\end{array}$ & $\begin{array}{c}65.09 \\
(53.76)^{\mathrm{e}}\end{array}$ & $\begin{array}{c}37.36 \\
(37.66)^{\mathrm{c}}\end{array}$ & $\begin{array}{c}56.88 \\
(48.93)^{\mathrm{e}}\end{array}$ & $\begin{array}{c}64.64 \\
(53.49)^{\mathrm{f}}\end{array}$ \\
\hline $\mathrm{T}_{6}:$ & $\begin{array}{c}61.43 \\
(51.58)^{\mathrm{a}}\end{array}$ & $\begin{array}{c}72.93 \\
(58.62)^{\mathrm{c}}\end{array}$ & $\begin{array}{c}79.45 \\
(63.02)^{\mathrm{c}}\end{array}$ & $\begin{array}{c}52.41 \\
(46.36)^{\mathrm{a}}\end{array}$ & $\begin{array}{c}73.38 \\
(58.91)^{\mathrm{c}}\end{array}$ & $\begin{array}{c}80.41 \\
(63.70)^{\mathrm{c}}\end{array}$ & $\begin{array}{c}56.92 \\
(48.96)^{\mathrm{a}}\end{array}$ & $\begin{array}{c}73.16 \\
(58.77)^{\mathrm{c}}\end{array}$ & $\begin{array}{c}79.93 \\
(63.36)^{\mathrm{c}}\end{array}$ \\
\hline $\begin{array}{r}\mathrm{T}_{7} \text { : Custard apple } \\
\text { (CASE)@ }\end{array}$ & $\begin{array}{c}36.35 \\
(37.06)^{\mathrm{c}}\end{array}$ & $\begin{array}{c}67.71 \\
(55.35)^{\mathrm{c}}\end{array}$ & $\begin{array}{c}70.11 \\
(56.83)^{\mathrm{d}}\end{array}$ & $\begin{array}{c}37.57 \\
(37.79)^{\mathrm{b}}\end{array}$ & $\begin{array}{c}65.33 \\
(54.91)^{\mathrm{d}}\end{array}$ & $\begin{array}{c}71.37 \\
(53.932)^{\mathrm{e}}\end{array}$ & $\begin{array}{c}36.96 \\
(37.43)^{\mathrm{c}}\end{array}$ & $\begin{array}{c}68.22 \\
(55.66)^{\mathrm{d}}\end{array}$ & $\begin{array}{c}70.74 \\
(57.23)^{\mathrm{e}}\end{array}$ \\
\hline $\mathrm{T}_{8}:$ CASE + & $\begin{array}{c}51.00 \\
(45.55)^{\mathrm{b}}\end{array}$ & $\begin{array}{c}70.62 \\
(57.15)^{\mathrm{c}}\end{array}$ & $\begin{array}{c}79.05 \\
(62.73)^{\mathrm{c}}\end{array}$ & $\begin{array}{c}52.44 \\
(46.38)^{\mathrm{a}}\end{array}$ & $\begin{array}{c}69.81 \\
(56.65)^{\mathrm{c}}\end{array}$ & $\begin{array}{c}77.71 \\
(61.806)^{\mathrm{d}}\end{array}$ & $\begin{array}{c}51.72 \\
(45.97)^{\mathrm{b}}\end{array}$ & $\begin{array}{c}70.21 \\
(56.90)^{\mathrm{c}}\end{array}$ & $\begin{array}{c}78.38 \\
(62.27)^{\mathrm{d}}\end{array}$ \\
\hline $\mathrm{T}_{9}: \mathrm{CASE}+\mathrm{PSE}$ & $\begin{array}{c}55.22 \\
(47.98)^{\mathrm{b}}\end{array}$ & $\begin{array}{c}65.50 \\
(54.01)^{\mathrm{c}}\end{array}$ & $\begin{array}{c}75.52 \\
(60.32)^{\mathrm{d}}\end{array}$ & $\begin{array}{c}54.78 \\
(47.72)^{\mathrm{a}}\end{array}$ & $\begin{array}{c}64.17 \\
(53.21)^{\mathrm{d}}\end{array}$ & $\begin{array}{c}76.52 \\
(60.99)^{\mathrm{d}}\end{array}$ & $\begin{array}{c}55.00 \\
(47.85)^{\mathrm{a}}\end{array}$ & $\begin{array}{c}64.84 \\
(53.61)^{\mathrm{d}}\end{array}$ & $\begin{array}{c}76.02 \\
(60.66)^{\mathrm{d}}\end{array}$ \\
\hline $\begin{array}{c}\mathrm{T}_{10}: \mathrm{CASE}+\mathrm{PSE}+\mathrm{NSKE}(1: 2: 2) @ \\
5 \%\end{array}$ & $\begin{array}{c}64.69 \\
(53.52)^{\mathrm{a}}\end{array}$ & $\begin{array}{c}80.44 \\
(63.72)^{\mathrm{b}}\end{array}$ & $\begin{array}{c}83.01 \\
(65.63)^{\mathrm{c}}\end{array}$ & $\begin{array}{c}57.33 \\
(49.20)^{\mathrm{a}}\end{array}$ & $\begin{array}{c}78.78 \\
(62.54)^{\mathrm{b}}\end{array}$ & $\begin{array}{c}83.57 \\
(66.06)^{\mathrm{c}}\end{array}$ & $\begin{array}{c}61.01 \\
(51.34)^{\mathrm{a}}\end{array}$ & $\begin{array}{c}79.61 \\
(63.13)^{\mathrm{b}}\end{array}$ & $\begin{array}{c}83.29 \\
(65.85)^{\mathrm{c}}\end{array}$ \\
\hline $\begin{array}{c}\mathrm{T}_{11} \text { :Agricultural spray oil (ASO)@2 } \\
\mathrm{ml} / 1\end{array}$ & $\begin{array}{c}28.38 \\
(32.18)^{\mathrm{d}}\end{array}$ & $\begin{array}{c}61.90 \\
(51.86)^{\mathrm{d}}\end{array}$ & $\begin{array}{c}71.12 \\
(57.47)^{\mathrm{d}}\end{array}$ & $\begin{array}{c}29.38 \\
(32.81)^{\mathrm{c}}\end{array}$ & $\begin{array}{c}60.33 \\
(50.94)^{\mathrm{e}}\end{array}$ & $\begin{array}{c}72.41 \\
(58.29)^{\mathrm{d}}\end{array}$ & $\begin{array}{c}28.88 \\
(32.49)^{\mathrm{d}}\end{array}$ & $\begin{array}{c}61.12 \\
(51.40)^{\mathrm{e}}\end{array}$ & $\begin{array}{c}71.76 \\
(57.88)^{\mathrm{e}}\end{array}$ \\
\hline $\begin{array}{c}\mathrm{T}_{12}: \text { ASO+ CASE + PSE+ NSKE } \\
(2: 1: 2: 2) @ 5 \%\end{array}$ & $\begin{array}{c}36.87 \\
(37.37)^{\mathrm{c}}\end{array}$ & $\begin{array}{c}98.51 \\
(82.95)^{\mathrm{a}}\end{array}$ & $\begin{array}{c}100 \\
(89.96)^{\mathrm{a}}\end{array}$ & $\begin{array}{c}39.60 \\
(38.98)^{b}\end{array}$ & $\begin{array}{c}96.99 \\
(79.98)^{\mathrm{a}}\end{array}$ & $\begin{array}{c}100.00 \\
(89.69)^{\mathrm{a}}\end{array}$ & $\begin{array}{c}38.24 \\
(38.18)^{\mathrm{c}}\end{array}$ & $\begin{array}{c}97.75 \\
(81.34)^{\mathrm{a}}\end{array}$ & $\begin{array}{c}100 \\
(89.69)^{\mathrm{a}}\end{array}$ \\
\hline $\mathrm{T}_{1}$ & $\begin{array}{c}53.44 \\
(46.95)^{\mathrm{b}} \\
\end{array}$ & $\begin{array}{c}71.59 \\
(57.76)^{\mathrm{c}} \\
\end{array}$ & $\begin{array}{c}91.95 \\
(73.49)^{\mathrm{b}} \\
\end{array}$ & $\begin{array}{c}52.33 \\
(46.32)^{\mathrm{a}} \\
\end{array}$ & $\begin{array}{c}73.44 \\
(58.96)^{\mathrm{c}} \\
\end{array}$ & $\begin{array}{c}93.67 \\
(75.39)^{\mathrm{b}} \\
\end{array}$ & $\begin{array}{c}52.89 \\
(46.64)^{\mathrm{b}} \\
\end{array}$ & $\begin{array}{c}72.52 \\
(58.36)^{\mathrm{c}}\end{array}$ & $\begin{array}{c}92.81 \\
(74.42)^{\mathrm{b}}\end{array}$ \\
\hline Em \pm & 0.73 & 1.23 & 1.06 & 0.98 & 0.84 & 1.06 & 1.00 & 0.77 & 0.67 \\
\hline $\mathrm{CD}(1 \%)$ & 2.86 & 4.83 & 4.17 & 3.85 & 3.30 & 4.16 & 3.93 & 3.01 & 2.58 \\
\hline C.V & 3.34 & 4.20 & 3.24 & 4.51 & 2.90 & 3.21 & 4.25 & 2.45 & 1.85 \\
\hline
\end{tabular}

NSKE - Neem seed kernel extract, PSE- Pongamia seed extract, CASE- Custard apple seed extract, ASO- Agricultural spray oil *Values inside the parenthesis are arc sin transformed.

\section{4 hrs after the treatment}

Among the different treatments tested, treatment $\left(\mathrm{T}_{10}\right)$ CASP + PSE+ NSKE (1:2:2) @ 5\% gave higher mortality $(64.69 \%)$ of aphids which was followed by $\left(\mathrm{T}_{9}\right)$ CASE+ PSE (1:1) @ $5 \%(55.22 \%)$, the chemical check Spinosad 2.5\% SC @ 0.5 $\mathrm{ml} / \mathrm{l}$ (T13) were statistically on par with each other in case of percent mortality caused. Combination products have shown more mortality than any individual biorational tested. When we look into the efficacy of two entomopathogenic fungi tested L. lecanii $\left(\mathrm{T}_{2}\right)$ produced maximum mortality $(22.54 \%)$ of aphids. Among the individual botanicals tried, NSKE (T4) (40.39\%) followed by CASE (T7) $(36.35 \%)$, PSE $(36.19 \%)$ have given maximum mortality and later two treatments were on par with each other. The treatment which has shown less effective after 24 hrs of treatment was Beauveria bassiana @ $10^{8} \mathrm{CFU} / \mathrm{g}\left(\mathrm{T}_{1}\right)$ with the aphid mortality per cent of 22.54 during the in vitro study of 2017. Results obtained during 2018 in vitro study has few variations too, as all the combination treatments except $\mathrm{T}_{12}$ was found to be on par with each other giving maximum aphid mortality which was on par with the chemical check $\mathrm{T}_{13}$. Other results obtained during 2018 were similar with the studies conducted during 2017 which was also true with the pooled data of both the years.

\section{8 hrs after treatment}

Data obtained after $48 \mathrm{hrs}$ after the treatment shows the change in the trend in the aphid mortality that $\mathrm{T}_{12}$ (ASO+ CASE + PSE+ NSKE (2:1:2:2) @5\%) produced maximum mortality of 98.51 per cent. Next best treatment after $\mathrm{T}_{12}$ was T10 (CASP + PSE+ NSKE (1:2:2) @ 5\%) with the recorded aphid mortality of 80.44 per cent which was followed by the chemical check $\left(\mathrm{T}_{13}\right)$. In case of individual botanicals tested
CASE@5\% $\left(\mathrm{T}_{7}\right)$ was leading in the mortality percentage (67.71\%) followed by NSKE $\left(\mathrm{T}_{4}\right)$ @ 5\% (63.90\%) and PSE $\left(\mathrm{T}_{5}\right) @ 5 \%(58.43 \%)$ and the later two treatments were found to be statistically on par with each other. Bioefficacy of the entomopathogen $L$. lecanii $\left(\mathrm{T}_{2}\right)(60.43 \%)$ was nearly double that of B. bassiana $\left(\mathrm{T}_{1}\right)(39.52 \%)$ after $48 \mathrm{hrs}$ of treatment. More or less similar result was obtained during the in vitro study of 2018. As it was also noticed that $\mathrm{T}_{12}$ was leading treatment causing higher mortality $(96.99 \%)$ followed by $\mathrm{T} 10$ $(78.78 \%)$. And the least performing treatment during both the year study was T13 (Hing @ $0.125 \%$ ) with the recorded aphid mortality per cent of 35.02 and 33.68 during 2017 and 2018 respectively.

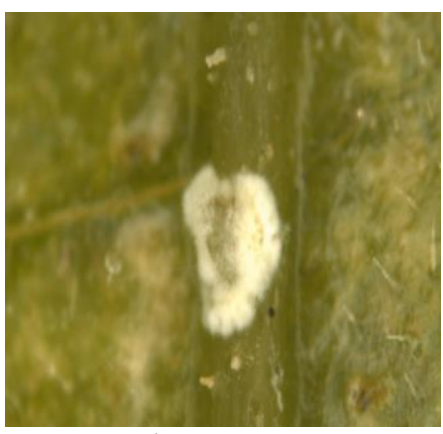

B. bassinana

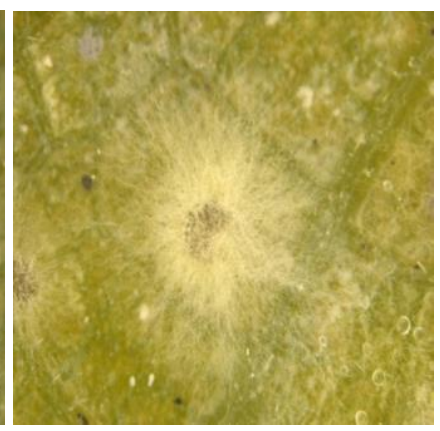

L. lecani
Fig 1: Aphids infected with Entomopathogenic fungi in laboratory condition

\section{2 hrs after treatment}

After $72 \mathrm{hrs}$ of treatment, $\mathrm{T}_{12}$ produced cent per cent mortality of the aphids which was followed by the chemical check $\mathrm{T}_{13}$ $(91.95 \%)$. In case of entomopathogenic fungi tested $T_{2}$ 
(Lecanicillium lecanii @ 108 CFU/g) had 82.90 per cent mortality of aphids and $\mathrm{T}_{1}$ (Beauveria bassiana @ $10^{8}$ $\mathrm{CFU} / \mathrm{g}$ ) gave 64.86 per cent mortality. Among the individual botanicals tested $\mathrm{T}_{4}$ gave more aphid mortality $(76.27 \%)$ but it was statistically on par with $\mathrm{T}_{7}$ with $(70.11 \%)$ aphid mortality percentage. During 2018, in vitro study also the same trend had been followed as $\mathrm{T}_{12}$ produced cent per cent mortality followed by the chemical check $\mathrm{T}_{13}$. All other results were also found to be on par with the 2017 studies and the least effective treatment among the biorationals tested was $\mathrm{T}_{3}$ with the aphid mortality percentage of 40.95 . The pooled table of aphid mortality percentage during both the laboratory studies of 2017 and 2018 is presented on the Table 31 also clearly shows that $T_{12}$ was the best treatment among the treatments tested which was only treatment that had produced cent per cent mortality of test insect. More importantly it had over performed even the chemical check, Spinosad which had the aphid mortality percentage of 92.81 .

The efficacy of various treatments as per the cumulative mortality after $72 \mathrm{hrs}$ was in the order of: $\mathrm{T}_{12}$ (ASO+ CASE + PSE+ NSKE (2:1:2:2) @ 5\%)> T 13 : Spinosad 2.5\% SC @ 0.5 $\mathrm{ml} / 1>\mathrm{T}_{2}$ : Lecanicillium lecanii @ 10 $\mathrm{CFU} / \mathrm{g}>\mathrm{T}_{10}(\mathrm{CASE}+$ PSE+ NSKE (1:2:2) @ 5\%)> T $($ CASP+NSKE (1:1) @ $5 \%)>\mathrm{T}_{9}(\mathrm{CASE}+\mathrm{PSE}(1: 1) @ 5 \%)>\mathrm{T}_{4}$ : NSKE @ 5\%> $\mathrm{T}_{11}$ $(\mathrm{ASO} @ 2 \mathrm{ml} / \mathrm{l})>\mathrm{T}_{7}(\mathrm{CASE} @ 5 \%)>\mathrm{T}_{1}\left(\right.$ B. bassiana @ $10^{8}$ CFU/g) $>\mathrm{T}_{5}$ (PSE@ 5\%)> T 3 (Hing @ 0.125\%).

\section{Discussion}

In case of A. gossypii the best biorationals combination which provided the maximum mortality of 100 per cent after $72 \mathrm{hrs}$ of treatment is $\mathrm{T}_{12}$ (ASO+ CASE + PSE+ NSKE (2:1:2:2) @ 5\%) followed by the chemical check Spinosad 2.5\% SC @ $0.5 \mathrm{ml} / 1(92.84 \%)$. This result is supported by Vignesh et al., $2019{ }^{\text {[39] }}$ who also reported that the combination of neem, pongamia, custard apple seed extracts and mineral oil mixture produced the synergetic action against the mites which gave better result than the chemical check. Studies of Rao et al., $2002{ }^{[28]}$ and Venkatesan et al., $2007^{[38]}$ was also in line with the present findings, as they also found the efficiency of using neem and pongamia extracts together.

In case of single botanicals tried NSKE caused more mortality of aphids $(75.93 \%)$ followed by CASE $(70.74 \%)$ after $72 \mathrm{hrs}$ of treatment. It is similar with the findings of (Ascher et al., 1984; Lowery et al., 1993; Kulat et al., 1997; Biswas, 2013; Chaudhary et al., 2017) ${ }^{[2,23,18,5,6]}$ who reported the same result as the present findings as neem to be a most effective pesticide against aphids and also there are similar demonstrations by (Schmutterer, 1990; Partridge and Borden, 1997; Tang et al., 2002) [31, 26, 35] stating that the active ingredient Azadiractin as reducing the survival period and fecundity of $A$. gossypii under laboratory condition. The efficiency of using custard apple seed extracts against sucking pests due to the active principle "Neoannonin" was also proved by several authors (Kawazu et al., 1989; Rupprecht et al., 1990; Lin et al., 2009) ${ }^{[17,29,21]}$ which was also true with the present evaluation.

It is also clear that among the entomopathogenic fungi tried Lecanicillium lecanii IOF (Accession number: IOF KM215209) strain 1 is proved to be effective against $A$. gossypi which is also in line with the studies of various authors like (Saito, 1988; Ramakers, 1989; Gindin et al., 1996; Nirmala et al. 2006; Alavo, 2015) [30, 27, 12, 25] who reported $L$. lecanii as a best entomopathogen to be used against the sucking pests under greenhouse condition.

\section{Conclusion}

Combination of biorationals produced better aphids mortality rather than going with the single botanicals. The entomopathogenic fungi Lecanicillium lecanii proved effective against aphids which have to be included in the integrated pest management programme along with the botanicals for improved results. Efficacy of using biorationals against $A$. gossypii is proved by the current study which has to be evaluated extensively under field condition in order to find the reliable alternative tool for prevailing chemical control measures.

\section{References}

1. Alavo TBC. The insect pathogenic fungus Verticillium lecanii (Zimm.) Viegas and its use for pests control: a review. J. Exp. Boil. Agril. Sci. 2015; 3(4):16.

2. Ascher KRS, Eliyahu M, Nemmy NE, Meisner J. Azadirachta indica NSKE as an inhibitor of growth and fecundity in Spodoptera littoralis. In: Natural Pesticides from the $A$. indica tree and other tropical plants (Eds., H. Shmutterer and K.R.S. Ascher) Proc. 2nd Int. A. indica. Conf. Rauischolzhausen, Germany, 1984, 331-344.

3. Barapatre AB. Evaluation of indigenous technology for management of Helicoverpa armigera (Hub.) and Spodoptera litura (Hub). M. Sc. (Agri.) Thesis, Uni. Agric. Sci., Dharwad (India), 2001.

4. Bennison J. Biological control of aphids on cucumbers use of open rearing systems or 'banker plants' to aid establishment of Aphidius matricariae and Aphidoletes aphidimyza. Mededelingen van de Faculteit Landbouwwetenschappen, Universiteit Gent., 1992; 57(2b):457-466.

5. Biswas GC. Comparative effectiveness of neem extracts and synthetic organic insecticide against mustard aphid, Bangladesh. J Agril. Res. 2013; 38(2):181-187.

6. Chaudhary S, Kanwar RK, Sehgal A, Cahill DM, Barrow CJ, Sehgal R et al. Progress on Azadirachta indica based biopesticides in replacing synthetic toxic pesticides. Front. Plant Sci., 2017; 8:610.

7. Crump NS, Cother EJ, Ash GJ. Clarifying the nomenclature in microbial weed control. Biocon Sci Tech. 1999; 9:89-97.

8. Dogan YO, Hazir S, Yildiz A, Butt TM, Cakmak I. Evaluation of entomo pathogenic fungi for the control of Tetranychus urticae (Acari: Tetranychidae) and the effect of Metarhizium brunneum on the predatory mites (Acari: Phytoseiidae). Biol. Contr. 2017; 111:6-12.

9. Eilenberg J, Hajek A, Lomer C. Suggestions for unifying the terminology in biological control. Bio Control. 2001; 46:387-400.

10. Elena AS, Maria OP, Taisiya DC, Roman P. Prospects for the Use of Pongamia pinnata Oil-Based Products against the Green Peach Aphid Myzus persicae (Sulzer) (Hemiptera: Aphididae). Psyche, Article ID 705397. 2014, 5.

11. Erler F, Ates A, Bahar Y. Evaluation of two entomopathogenic fungi, Beauveria bassiana and Metarhizium anisopliae, for the control of carmine spider mite, Tetranychus cinnabarinus (Boisduval) under greenhouse conditions. Egyptian J. Biol. Pest Cont. 2013; 23(2):233.

12. Gindin G, Barash I, Raccah B. The potential of some entomopathogenic fungi as biocontrol agents against the onion thrips, Thrips tabaci and the western flower thrips, 
Frankliniella occidentalis. Folia Ent. Hung. 1996; 57:3742.

13. Gomez KA, Gomez AA. Statistical procedures for agricultural research (2 ed.). John wiley and sons, New York, 1984, 680.

14. Hassan MF, Ali FS, Hussein AM, Mahgob MH. Biological and chemical control of three plant piercing sucking insect pests on cucumber in plastic houses. Egyptian J. Biol. Pest Cont. 2008; 18(1):167-170.

15. Hiremath IG, Joon AY, Soon K. Insecticidal activity of Indian plant extracts against Nilaparvata lugens (Homopera: Delphacidae). Appl. Ent. Zool. 1997; 32:159-166.

16. Katole SR, Thakare HS, Mahajan RK. Effect of some plant products on the infestation of leaf miner on Nagpur mandrin. J. Maharastra Agril. Univ. 1993; 18:67-68.

17. Kawazu K, Alcantara JP, Kobayashi A. Isolation and structure of neoannonin, a novel insectidal compound from seeds of Annona squamosa. Agric. Biol. Chem., 1989; 53:2719-2722.

18. Kulat SS, Nimbalkar SA, Hiwase BJ. Relative efficacy of some plant extracts against Aphis gossypii (Glover) and Amrasca devastans (Distant) on okra. PKV Res. J., 1997; 21:146-148.

19. Kumar M, Singh R. Potential of Pongamia glabra vent as an insecticide of plant origin. Biol. Agric. Hortic. 2002; 20(1):29-50.

20. Labbe R, Gillespie DR, Cloutier C, Brodeur J. Compatibility of an entomopathogenic fungus with a predator and a parasitoid in the biological control of greenhouse whitefly. Biocontrol Sci. Technol. 2009; 19(4):429-446.

21. Lin C, Wu DC, Yu J, Chen B, Wang C, Ko W. Control of silverleaf whitefly, cotton aphid and kanzawa spider mite with oil and extracts from seeds of sugar apple.. Neotrop. Entomol, 2009; 38(4):531-536.

22. Loganathan J, Dhingra S, Walia S. Efficacy of Pongamia glabra Vent. extracts on feeding and development of Spodoptera litura (Fabricius), Pesticide Res. J. 2006; 18(1):15-19.

23. Lowery D, Isman M, Brard N. Laboratory and field evaluation of neem for the control of aphids (Homoptera: Aphididae). J. Econ. Entomol., 1993; 86(3):864-870.

24. Mhazo ML, Mhazo N, Masarirambi MT. The effectiveness of homemade organic pesticides derived from wild plants (Solanum pindiriforme and Lippia javanica), garlic (Allium sativum) and tobacco (Nicotiana tobacum) on aphid (Brevicoryne brassica) mortality on rape (Brassica napus) plants. Res. J. Environ. Earth Sci., 2011; 3(5):457-462.

25. Nirmala R, Ramanujam B, Rabindra RJ, Rao NS. Effect of entomofungal pathogens on mortality of three aphid species. J. Biol. Contr. 2006; 20(1):89-94.

26. Partridge M, Borden JH. Evaluation of neem seed extract for control of the spruce aphid, Elatobium abietinum (Walker) (Homoptera: Aphidae). Canadian Entomol. 1997; 129:899-906.

27. Ramakers PMJ. Biological control in greenhouses. In world crop pests (Editor in Chief: Helle W.); Aphids, their biology, natural enemies and control (eds. Minks, A. K., Harrewijn, P.). 1989; 2(C):199-208.

28. Rao NS, Rajendran R, Raguraman S. Antifeedant and growth inhibitory effects of neem in combination with sweet flag and pungam extracts on okra shoot and fruit borer Earias vittella. J. Ent. Res. 2002; 26:233-238.
29. Rupprecht JK, Hui YH, McLaughlin JL. Annonaceous acetogenins: a review. J. Nat. Prod. 1990; 53:237-278.

30. Saito T. Control of Aphis gossypii in greenhouses by a mycoinsecticidal preparation of Verticillium lecanii and effect of chemicals on the fungus. Japan J. Appl. Entomol. Zool. 1988; 32:224-227.

31. Schmutterer H. Properties and potential of natural pesticides from the neem Azadirachta indica tree. Ann. Rev. Entomol.1990; 35:271-297.

32. Sedlacek JD, Townsend LH. Demography of the red form of Myzus nicotianae (Homoptera: Aphididae) on burley tobacco. J. Econ. Entomol. 1990; 83(3):10801084.

33. Shipp JL, Boland GJ, Shaw LA. Integrated pest management of disease and arthropod pests of greenhouse vegetable crops in Ontario: Current status and future possibilities. Canadian J. Plant Sci. 1991; 71:887914.

34. Stein U, Klingauf F. Insecticidal effect of plant extracts from tropical and subtropical species. J. Appl. Entomol., 1990; 110:160-166.

35. Tang YQ, Weathersbee AA, Mayer RT. Effect of neem extract on the brown citrus aphid (Homoptera: Aphididae) and its parasitoid Lysiphlebus testaceipes (Hymenoptera: Aphididae). Environ. Entomol. 2002; 31:172-176.

36. Tehri K, Gulati R, Geroh M. Damage potential of Tetranychus urticae Koch to cucumber fruit and foliage: Effect of initial infestation density. J. Appl. Nat. Sci. 2014; 6(1):170-176.

37. Ugine TA, Wraight SP, Brownbridge M, Sanderson JP. Development of a novel bioassay for estimation of median lethal concentrations (LC50) and doses (LD50) of the entomopathogenic fungus Beauveria bassiana, against western flower thrips, Frankliniella occidentalis. J. Invertebr. Pathol., 2005; 89(3):210-218.

38. Venkatesan K, Chandrashekar K, Chandrasheka, Sidhu OP. Synergistic action of neem and karanj to aphids and mites. J. Entomol. Res. 2007; 31(2):121-124.

39. Vignesh M, Patil RK, Udhayakumar VS. Evaluation for promising biorationals and their synergetic combination against the two spotted spider mite Tetranychus urticae Koch. Journal of Entomology and Zoology Studies. 2019; 7(4):356-360.

40. Ware GW, Whitacre DM. The Pesticide Book. Meister Pro Information Resources. Willoughby, 2004, 488.

41. Yasarakinci N, Hincal P. Determining the pests and beneficial spices and their population densities on tomato, cucumber, pepper and lettuce greenhouse in Izmir. Bitki Koruma Bulltin. 1997; 37:79-89. 